\title{
Discussion on the Dilemmas and Countermeasures of the Modern Apprenticeship in the Financial Management Major of Universities
}

Song Wen

College of Science and Technology of China Three Gorges University, Yichang 443000, Hubei Province, China

\begin{abstract}
With the advancement of "high quality vocational school scheme" and "double first-class college" construction in China, more and more colleges and universities have begun to adopt modern apprenticeship to create a new "dual subject" education model. That way, it will improve the quality of education in Chinese universities. As economic transformation is speeding up, financial management has become a popular major in colleges and universities. There is a great demand for high-quality financial management elites. Colleges and universities must begin with the school-enterprise cooperation, connection between industry and core curriculum, docking between diploma and professional qualification certificate to ease the intensive modern apprenticeship of the financial management majors. This will let the modern apprenticeship be deeprooted in the financial management major class, comprehensively improving the students' ability to adapt to their positions.
\end{abstract}

Keywords: Colleges and universities, Financial management, Modern apprenticeship, Dilemmas and countermeasures

Publication date: December, 2020

Publication online: 31 December, 2020

"Corresponding author: Song Wen, 2914622351@, qq.com

In 2017, the State Council issued the Guiding Opinions on Carrying out Quality Improvement Actions which clearly proposed that it is necessary to promote the joint training of quality talents by enterprises and vocational colleges. It will further implement the modern and the new enterprise apprenticeship system. This document points out the direction for the construction of modern apprenticeship in universities. Financial management is mainly to train talents in the field of banking, securities and insurance. Students must not only have solid financial knowledge, but also be proficient in processing practical financial skills. That being said, modern apprenticeship can meet the teaching needs of financial management majors. Based on the employment orientation of the financial management industry, colleges and universities should develop a new core curriculum. They should actively create a teaching mechanism of "dual tutors" and invite financial managers in the corporate to participate in teaching activities. They need to change the training model of financial talents, spreading the " $1+X "$ certificate system, and encouraging students to obtain financial qualification certificates. Universities should also promote the strategy of integrating production and education and school-enterprise joint construction of training bases. Enterprise masters and teachers jointly carry out practical training to enhance practical ability of students.

\section{Difficulties faced by college financial management majors in developing modern apprenticeship}

\subsection{The scope of school-enterprise cooperation is relatively monotonous and lacks in-depth cooperation mechanisms}

The advantage of modern apprenticeship is the organic combination of vocational education and job 
practice. Although many colleges and universities have begun to implement modern apprenticeship, the way of school-enterprise cooperation is slightly simple. For example, colleges and universities mainly adopt order-based training programs. Enterprises and universities sign employment agreements. The university organizes graduates to go to the company for internships every year. However, the company does not participate in the curriculum design and practical teaching sections. The financial managers in the enterprises rarely participate in teaching students. Some advanced financial operation platforms of enterprises have not been applied into the teaching of professional courses. This kind of cooperation will also affect the teaching effect of modern apprenticeship.

\subsection{The employment orientation is not smoothly connected with the curriculum.}

Many financial management students are confused about their future career because there are many financial management courses in college, and modern apprenticeship has not yet applied into the teaching of financial management courses. The connection between job skills and professional courses in financial enterprises is not reasonable, so the employment orientation is vague. For example, most of the financial management administrators in college arrange for students to go to banks, securities and insurance companies for internships in the last semester, which is failed to integrated relevant job skills into professional teaching. Students have relatively few practical skills in the financial industry during their school years. All of these will affect the employment rate and employment quality of finance majors.

\subsection{The collaborative educational mechanism is} not perfect, while the financial practical skills of students are relatively insufficient.

The core of modern apprenticeship is to create a collaborative education mechanism by universities and enterprises. Enterprises provide specialized production facility, while enterprise technicians explain vocational skills and how to operate professional equipment. Finance management majors also use information platforms, such as banking operating systems, securities software, and foreign exchange computing systems. These specialized platforms need to be provided by enterprises.
However, the cooperation between universities and financial enterprises is relatively monotonous. There is relatively little cooperation in terms of financial informational platform and financial practical operations, which affects the improvement of students' financial practical ability to a certain extent.

\section{The necessity of developing modern apprenticeship for financial management majors in colleges and universities in the new era}

\subsection{Accelerating the construction of a school- enterprise collaborative education pattern}

Modern apprenticeship make school-enterprise cooperation more dynamic. For financial management majors in colleges and universities, modern apprenticeship provides a new school-enterprise cooperation model. The financial management major can introduce the advanced information platform of financial enterprises, brand-new concepts of financial management through modern apprenticeships. This will further improve the core curriculum of financial management majors. Enterprises can select highquality graduates through the modern apprenticeship system, focusing on training outstanding students in financial management. It will set a basement of young talents in enterprises, thereby comprehensively improving the teaching quality of financial management in colleges and universities.

\subsection{Highlighting the employment orientation of financial management majors}

Financial management majors in colleges and universities should follow the development trend of financial industry in China, such as Internet finance, stock market and funds and other popular financial development. Colleges and universities should actively seek the cooperation of these enterprises, combining with new banking qualifications, financial planners, certified public accountants and securities qualifications to help students clarify their career plans. The modern apprenticeship system can integrate financial management job skills into the teaching of various courses, carry out practical teaching according to financial professional qualifications, and propose teaching by mission and cases presentation. That being said, it will realize the perfect connection between employment and financial 
management teaching.

\section{Countermeasures to develop modern apprenticeship for financial management majors in colleges and universities}

\subsection{Developing core curriculum based on the employment orientation of the financial industry}

Colleges and universities should comprehensively investigate the development trend of the financial industry, analyzing the recruitment needs of the banking, securities, and insurance industries, optimize the financial management curriculum system, and develop a new core curriculum. The modern apprenticeship system can integrate brandnew financial management concepts and job skills into the teaching of professional courses, while developing a core curriculum for the financial management with characteristics. For example, following the development trend of Internet finance, colleges and universities develop core courses such as "Analysis of P2P Financial Management Models", "Internet Financial Risk Assessment" and "Securities Investment Evaluation" to integrate popular financial management concepts into teaching, thereby enhancing professional teaching. For instance, the school can invite financial planners, securities experts and insurance specialists in financial companies to participate in the development of curriculum resources. Financial managers can provide some real cases, such as financial management cases, securities investment cases, and fund returns. So, teachers can create curriculum resources based on these cases, such as video resources, financial management plans and income calculation methods, to improve the school's financial management professional curriculum. Integrating financial management skills into the core curriculum group will comprehensively improve the teaching quality of financial management.

\subsection{Inviting companies to participate in teaching with the "dual tutor" teaching mechanism}

Enterprises are important participants in the modern apprenticeship system. Colleges and universities should actively build a "dual subject" collaborative education system, inviting financial companies to participate in teaching. It will incorporate the latest financial management concepts into teaching. For example, college can invite bank cashier, securities analysts and financial planners to participate in training and teaching. College and enterprises can jointly build training bases on campus, introducing bank simulation systems, securities investment systems and insurance contracts. Financial managerial staff can explain the operation of the system to students. For example, bank tellers can demonstrate how to operate deposit system, foreign exchange calculations and loan interest rate calculations for students. Tellers can explain while operating so that students can be trained according to the presentation of bank tellers. This will improve the financial practical processing capabilities of students. Securities analysts can analyze the stock markets of Shenzhen and Shanghai stock markets and explain the operation steps of the securities system, such as the timing of buying and selling stocks in different sectors, or how to analyze stock market trends. That way, it will make students sensitive to the financial market. Teachers and corporate financial managers can jointly carry out practical training and design different training projects, such as bank foreign exchange, deposit and withdrawal system operations, securities buying and selling operations, and other training projects. Related staff in financial enterprise will make comments on the operations of students, from the perspective of system operation of students, continuity and service language. It will comprehensively improve the quality of practical teaching of financial management in colleges and universities, and give full play to the advantages of the "dual tutor" teaching mechanism.

\subsection{Transforming the concept of financial managerial personnel training and spreading the " $1+X "$ certificate system}

Colleges and universities should take the initiative to change the concept of educating people in the financial management profession, encouraging financial management teachers and students to obtain relevant professional certificates, such as securities qualification certificates and certified public accountants. It will continuously improve the financial management students' own quality. Vocational qualification certificates can help students gain a position in the job application. For example, colleges and universities should collect relevant examination questions of qualification certificate to carry out targeted teaching. They should set up special training for qualification certificate examination 
by using modern apprenticeship, inviting banking, securities and insurance companies to conduct teaching, and explain different types of qualification certificate examination questions, such as explaining questions in the banking qualification certificate. Special training is carried out for banknote counting, system operation, service awareness and wealth management product introduction. The passing rate of students' exams is improved. College can organize skills competitions on campus, with senior financial managers serving as judges, The students are assessed in terms of theoretical knowledge and practical operation, encouraging more students to participate in the financial vocational qualification examination. This will enhance competitiveness of students in the future career.

\section{Implementing the strategy of integration of production and education, and jointly building a training base by schools and enterprises}

Based on the characteristics of the financial management profession, colleges and universities should develop a new path of integration of production and education, jointly build a training base by colleges and enterprises. They will introduce professional financial management equipment and systems. That being said, it will promote the integration of modern apprenticeship and financial management teaching. For example, colleges and universities should regularly organize students to observe financial companies, transforming the companies into off-campus training bases. College should carry out professional training with the help of corporate professional financial management systems and tools. For example, college teachers lead students to observe the business models of securities companies and insurance companies, understanding the working models of various banks and different financial products. Students will learn financial management skills from the masters of financial companies to improve their job competitiveness. Universities can also invite financial companies to participate in the construction of on-campus training bases, such as ERP sand tables, bank management systems, and securities software, and jointly purchase the equipment with corporate funds. Financial managers and teachers can together carry out training and develop new school-based training courses. For example, the college can design training projects of securities practical operation, while the securities managers will assign corresponding tasks, such as analyzing the trend of A shares, screening out the potential stocks recently invested, and allowing students to find the latest potential stocks. The security managers can explain the trend of the stock market, the skills to avoid the risks, and the difference between stocks and funds. This will cultivate students' precise investment judgement, so that students can be qualified for more financial management positions.

\section{Conclusion}

In short, the modern apprenticeship system is an important measure for the transformation of universities in our country. The financial management majors in universities should give a full play to the advantages of their profession, using modern apprenticeship as a turning point to develop a new professional curriculum of financial management. College and enterprises should jointly establish internal and external training bases, following the employment orientation of financial industry. That being said, they will implement the " $1+X "$ certificate system, enhance the employment competitiveness of students, and deliver more high-quality financial management talents to market.

\section{References}

[1] Zhong MC, Yi XM. The innovation of higher vocational financial management professional talent training model based on modern apprenticeship [J]. Hebei Vocational Education, 2019, 3(04): 79-83.

[2] Huang YT, Mei HN. Discussion on the trial of modern apprenticeship system for finance majors in higher vocational colleges_-Taking Jiangmen Vocational and Technical College as an example [J]. Cultural Innovation Comparative Research, 2020, 4(30): 67-69.

[3] Li X. On the dilemma of modern apprenticeship in financial management majors in higher vocational colleges $[\mathrm{J}]$. China Management Information, 2019, 22(14): 201-203.

[4] Zhao M. Exploration of the construction of financial management major in higher vocational colleges under the background of modern apprenticeship [J]. Science and Technology Innovation Herald, 2019, 16(19): 193-194.

[5] Lu YF. The reform and practice of the modern apprenticeship training model for financial management majors-Taking Changchun Finance College as an example[J]. Science Education Journal (First half issue), 2019(06): 26-27. 